\title{
Pengaruh Inkuiri Terbimbing pada Kemampuan Akademik Berbeda terhadap Keterampilan Berpikir Kritis Siswa SMA
}

\author{
Diana Husna ${ }^{1}$, Sri Endah Indriwati ${ }^{1}$, Murni Saptasari ${ }^{1}$ \\ ${ }^{1}$ Pendidikan Biologi-Universitas Negeri Malang
}

\begin{tabular}{l}
\hline \hline INFO ARTIKEL \\
\hline RiwayatArtikel: \\
Diterima: 07-05-2019 \\
Disetujui: 22-01-2020 \\
\hline
\end{tabular}

kata kunci:

guided inquiry; academic ability; critical thinking skills; inkuiri terbimbing; kemampuan akademik; keterampilan berpikir kritis

\author{
AlamatKorespondensi: \\ Diana Husna \\ Pendidikan Biologi \\ Universitas Negeri Malang \\ Jalan Semarang 5 Malang \\ E-mail: dianahusna@gmail.com
}

\begin{abstract}
ABSTRAK
Abstract: This study aims to examine the effect of guided inquiry on different academic abilities towards critical thinking. The study was conducted by quasi experimental research with pre test-post test non equivalent control group design. Research subject consists of two classes. Critical thinking were measured by validated test. The data was analyzed using t-test at $\alpha=5 \%$ significance level. The results of the study are (1) implementation of guided inquiry have significant effect towards critical thinking, (2) academic abilities have significant effect towards critical thinking, and (3) there is no interaction between guided inquiry and academic abilities towards critical thinking.

Abstrak: Penelitian ini bertujuan untuk menguji pengaruh inkuiri terbimbing pada kemampuan akademik berbeda terhadap keterampilan berpikir kritis. Penelitian menggunakan metode eksperimen semu dengan rancangan pre test-post test non equivalent control group design. Subjek penelitian terdiri dari dua kelas. Keterampilan berpikir kritis diukur menggunakan instrumen tes berpikir kritis yang telah divalidasi. Data dianalisis dengan uji t pada taraf signifikansi $\alpha=5 \%$. Hasil penelitian menunjukkan bahwa (1) penerapan inkuiri terbimbing berpengaruh signifikan terhadap keterampilan berpikir kritis, (2) kemampuan akademik berpengaruh signifikan terhadap keterampilan berpikir kritis, dan (3) tidak ada pengaruh interaksi antara inkuiri terbimbing dan kemampuan akademik terhadap keterampilan berpikir kritis.
\end{abstract}

Keterampilan berpikir perlu dikembangkan untuk menghadapi tantangan hidup abad 21. Salah satu keterampilan berpikir yang berkaitan dengan kemampuan seseorang dalam memecahkan masalah adalah Keterampilan Berpikir Kritis (critical thinking skills). Facione (2013) mendefinisikan berpikir kritis sebagai pengaturan diri berupa interpretasi, analisis, evaluasi, dan inferen si, maupun penjelasan menggunakan bukti, konsep, metodologi, kriteria, atau pertimbangan kontekstual yang mendasari pengambilan keputusan. Ennis (2011) mendefinisikan berpikir kritis sebagai keterampilan berpikir reflektif dengan tujuan untuk mengambil keputusan berdasarkan hal yang diyakini dan harus dilakukan. Zubaidah (2002) mengemukakan berpikir kritis sebagai kemampuan melihat dan memecahkan masalah yang didalamnya terdapat rasa ingin tahu, imajinatif, berani menanggung resiko, serta menghargai hak, arahan, dan bimbingan orang lain. Merujuk pada definisi tersebut, keterampilan berpikir kritis adalah keterampilan yang perlu dikuasai siswa karena berhubungan dengan kemampuan siswa untuk melihat dan membaca situasi, serta mengumpulkan dan memilah informasi sehingga dapat digunakan sebagai pertimbangan dalam mencari solusi dan mengambil keputusan.

Berpikir kritis merupakan salah satu keterampilan yang perlu dilatihkan pada siswa. Pujiono (2012) menjelaskan bahwa siswa yang telah menguasai keterampilan berpikir kritis dapat menyelesaikan masalah melalui berbagai sudut pandang, percaya diri, bijaksana, kreatif, teliti, dan memiliki keyakinan yang kuat. Senada dengan itu, Hassoubah (2004) menyatakan bahwa penguasaan keterampilan berpikir kritis tinggi menyebabkan seseorang lebih kritis dalam mengatasi permasalahan. Namun, fakta yang didapatkan melalui wawancara guru Biologi kelas XI dan observasi pelaksanaan pembelajaran pada kelas XI pada tahun ajaran 2018-2019 di SMAN 7 Malang menunjukkan belum ada pengembangan keterampilan berpikir kritis siswa. Corebima dan Agil (2006) memaparkan bahwa pembelajaran di Indonesia kurang atau bahkan tidak memperhatikan dan melaksanakan pembelajaran yang memberdayakan keterampilan berpikir. 
Lai (2011) memaparkan bahwa pengembangan keterampilan berpikir kritis dapat diupayakan melalui penerapan model pembelajaran kooperatif dan pendekatan konstruktivisme yang memposisikan siswa sebagai pusat pembelajaran. Model pembelajaran inkuiri terbimbing dapat diterapkan untuk melatih keterampilan berpikir kritis. Pembelajaran inkuiri terbimbing dilaksanakan dalam kelompok dengan melibatkan bimbingan guru untuk membangun dan memperdalam pemahaman suatu konsep sains. Minner (2010) menjelaskan bahwa adanya bimbingan guru pada pembelajaran inkuiri terbimbing mampu meningkatkan pemahaman dan pembentukan konsep sains sehingga lebih terarah dan tepat, sesuai dengan indikator kompetensi yang akan dicapai. Hapsari (2012) melaporkan bahwa inkuiri terbimbing berpengaruh terhadap keterampilan berpikir kritis.

Pencapaian penguasaan keterampilan berpikir kritis dipengaruhi oleh kemampuan akademik. Ramdani (2012) melaporkan bahwa tingkat kemampuan akademik berbeda memiliki pengaruh yang signifikan pada penguasaan keterampilan berpikir kritis. Kemampuan akademik adalah kecakapan menyelesaikan masalah atau tugas yang dihadapi oleh siswa sesuai dengan pengetahuan yang dimiliki (Woolfolk, 2010). Arikunto (2012) menjelaskan bahwa kemampuan akademik siswa dapat ditentukan dari hasil tes. Lebih lanjut Nasution (2008) menjelaskan bahwa distribusi angka hasil tes dapat dikategorikan menjadi tiga kelompok, yaitu kelompok akademik tinggi, kelompok akademik tengah, dan kelompok akademik rendah. Kelompok yang menunjukkan perbedaan pencapaian keterampilan, termasuk dalam pencapaian keterampilan berpikir kritis adalah kelompok akademik tinggi dan kelompok akademik rendah. Mamu (2014) mengungkapkan bahwa siswa pada kelompok akademik tinggi berpotensi mengembangkan keterampilan berpikir kritis lebih baik dibandingkan siswa pada kelompok akademik rendah. Hasil penelitian Mamu tersebut sesuai dengan pernyataan Hamalik (2007) bahwa kemampuan akademik siswa dapat berpengaruh terhadap keberhasilan proses pendidikan. Berdasarkan pemaparan tersebut, peneliti melakukan penelitian tentang pengaruh model pembelajaran inkuiri terbimbing pada kemampuan akademik berbeda terhadap keterampilan berpikir kritis siswa kelas XI SMAN 7 Malang.

\section{METODE}

Penelitian dilaksanakan di SMAN 7 Malang kelas XI pada semester gasal 2018/2019. Populasi penelitian mencakup seluruh siswa kelas XI MIPA SMAN 7 Malang tahun ajaran 2018/2019 dengan jumlah 170 siswa yang tersebar menjadi enam kelas. Sampel dipilih secara acak setelah dilakukan uji normalitas dan homogenitas pada populasi. Rata-rata kemampuan akademik diuji menggunakan analisis one way ANAVA dengan tingkat signifikasi 0,05 pada nilai rapor mata Pelajaran Biologi semester gasal tahun 2017/2018. Kemampuan kognitif kelas XI MIPA sebanyak empat kelas adalah setara, yaitu XI MIPA 1, XI MIPA 2, XI MIPA 3, dan XI MIPA 4. Kelas eksperimen (XI MIPA 3) diberikan pembelajaran inkuiri terbimbing, sedangkan kelas kontrol (XI MIPA 2) diberikan pembelajaran konvensional, yaitu penbelajaran yang diterapkan guru Biologi di sekolah.

Pengumpulan data dilakukan melalui dokumentasi dan tes. Data kemampuan akademik diperoleh melalui dokumentasi nilai rapor. Data Keterampilan Berpikir Kritis dikumpulkan mengunakan instrumen tes berupa soal essay yang sudah divalidasi. Data nilai tes keterampilan berpikir kritis diperoleh melalui pre test dan post test. Data hasil penelitian dianalisis menggunakan statistik analisis kovarian (ANAKOVA) pada taraf signifikansi 0,5\%. Uji normalitas dilakukan menggunakan uji One-Sample Kolmogorov-Smirnov. Uji homogenitas dilakukan menggunakan Levene's Test of Equality of Error Variances.

\section{HASIL}

Data Keterampilan Berpikir Kritis berupa nilai tes berpikir kritis pada materi sistem gerak dan sistem sirkulasi. Nilai berpikir kritis kemudian dikelompokkan ke dalam lima kategori, yaitu sangat baik, baik, sedang, kurang, dan sangat kurang (Sugiyono, 2015). Nilai berpikir kritis tertinggi pada kelas eksperimen mencapai 77 (baik) dan nilai terendah sebesar 31 (kurang). Sedangkan pada kelas kontrol,nilai berpikir kritis tertinggi sebesar 48 (sedang) dan nilai terendah sebesar 23 (kurang). Rata-rata nilai berpikir kritis disajikan pada histogram gambar 1. Persentase siswa pada setiap kategori berpikir kritis tercantum pada tabel 1 .

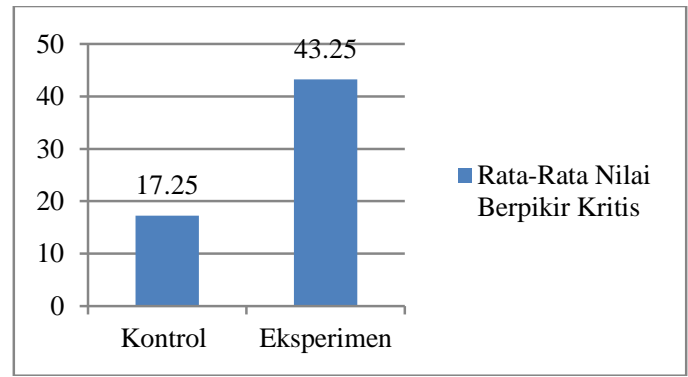

Gambar 1. Histogram Rata-Rata Nilai Berpikir Kritis pada Kelas Kontrol dan Eksperimen 
Tabel 1. Persentase Nilai Siswa pada Kategori Berpikir Kritis

\begin{tabular}{lrr}
\hline \multirow{2}{*}{ Kategori Keterampilan Berpikir Kritis } & \multicolumn{2}{c}{ Persentase (\%) } \\
\cline { 2 - 3 } & Kelas Kontrol & Kelas Eksperimen \\
\hline Sangat baik $(80,00-100)$ & 0 & 0 \\
Baik $(60,00-79,99)$ & 0 & 19,35 \\
Sedang $(40,00-59,99)$ & 21,21 & 61,29 \\
Kurang $(20,00-39,99)$ & 78,78 & 19,35 \\
Sangat kurang $(0-19,99)$ & 0 & 0 \\
\hline
\end{tabular}

(Modifikasi dari Sugiyono, 2015)

Data pada tabel 1 menunjukkan persentase keterampilan berpikir kritis siswa pada eksperimen dan kelas kontrol. Persentase keterampilan berpikir kritis pada kategori baik hanya muncul pada kelas eksperimen, dengan angka $19,35 \%$. Frekuensi keterampilan berpikir kritis dengan kategori sedang pada kelas eksperimen mencapai 61,29\%. Angka ini jauh lebih tinggi dibandingkan frekuensi keterampilan berpikir kritis kategori sedang pada kelas kontrol yang memperoleh persentase sebesar 21,21\%. Persentase keterampilan berpikir kritis dengan kategori kurang pada kelas eksperimen sebesar 19,35\%. Angka ini jauh lebih rendah dibandingkan dengan persentase keterampilan berpikir kritis siswa kategori kurang pada kelas kontrol yang mencapai $78,78 \%$.

Hasil uji normalitas data menunjukkan bahwa data berdistribusi normal dengan sig 0,190 (>0,05). Hasil uji homogenitas data menunjukkan bahwa varian data homogen dengan perolehan koefisien statistik Levene's sebesar 0,111 (>0,05). Hasil analisis pengaruh model pembelajaran inkuiri terbimbing, kemampuan akademik, serta interaksi model pembelajaran inkuiri terbimbing dan kemampuan akademik terdapat pada tabel 2.

Tabel 2. Pengaruh Inkuiri Terbimbing, Kemampuan Akademik, Serta Interaksi Antara Inkuiri Terbimbing Dan Kemampuan Akademik terhadap Keterampilan Berpikir Kritis

\begin{tabular}{lcccc}
\hline \multicolumn{1}{c}{ Variabel } & Jumlah Kuadrat & Df & F & Sig \\
\hline Model Pembelajaran Inkuiri Terbimbing & 3724,805 & 1 & 56,158 & 0,000 \\
Kemampuan Akademik & 692,817 & 1 & 10,446 & 0,003 \\
Interaksi Model pembelajaran dan Kemampuan Akademik & 229,451 & 1 & 3,459 & 0,070 \\
\hline
\end{tabular}

Data pada tabel 2 menunjukkan perolehan F hitung untuk model pembelajaran inkuiri terbimbing sebesar 56,158 dan sig $0,000(<0,05)$. Artinya terdapat perbedaan keterampilan berpikir kritis yang signifikan pada kelas yang diterapkan pembelajaran inkuiri terbimbing dan kelas yang menggunakan pembelajaran konvensional. Perolehan $\mathrm{F}$ hitung untuk kemampuan akademik sebesar 10,446 dan sig 0,003 (<0,05). Artinya, terdapat perbedaan Keterampilan Berpikir Kritis yang signifikan pada siswa kemampuan akademik tinggi dan siswa kemampuan akademik rendah. Dengan kata lain, tingkat kemampuan akademik siswa (tinggi dan rendah) berpengaruh signifikan terhadap perkembangan keterampilan berpikir kritis. Perolehan F hitung untuk interaksi antara inkuiri terbimbing dan kemampuan akademik sebesar 3,459 dan sig 0,070 (>0,05). Hal ini bermakna bahwa tidak ada pengaruh interaksi model pembelajaran inkuiri terbimbing dan kemampuan akademik terhadap keterampilan berpikir kritis.

\section{PEMBAHASAN}

Hasil penelitian ini memperlihatkan bahwa keterampilan berpikir kritis pada kelas yang diterapkan model pembelajaran inkuiri terbimbing berbeda signifikan dengan kelas yang diterapkan pembelajaran konvensional. Keterampilan berpikir kritis pada kelas yang diterapkan model pembelajaran inkuiri terbimbing terdapat pada kategori kurang, sedang, dan baik dengan persentase beruturut-turut 19,35\%, 61,29\%, dan 19,35\%. Sedangkan keterampilan berpikir kritis pada kelas yang diterapkan pembelajaran konvensional terdapat pada kategori kurang dan sedang dengan persentase 21,21\% dan 78,78\%. Data ini menunjukkan bahwa penguasaan keterampilan berpikir kritis lebih unggul pada kelas yang diterapkan pembelajaran inkuiri terbimbing.

\section{Pengaruh Inkuiri Terbimbing terhadap Keterampilan Berpikir Kritis}

Uji anakova ganda pada nilai pre test dan post test menunjukkan terdapat pengaruh signifikan penerapan model pembelajaran inkuiri terbimbing terhadap keterampilan berpikir kritis dengan nilai Sig. sebesar 0,000 (<0,05). Model pembelajaran inkuiri terbimbing terdiri atas tahapan-tahapan pembelajaran berupa menyusun pertanyaan berdasarkan masalah/fenomena, menyusun hipotesis, menghimpun data, menganalisis data, dan menarik kesimpulan. Hendi (2010) melaporkan bahwa pembelajaran berbasis inkuiri terbimbing mampu meningkatkan pemahaman siswa dengan memposisikan siswa untuk terlibat aktif dalam proses pembelajaran. Model pembelajaran inkuiri terbimbing melalui tahapan-tahapan pembelajarannya berpotensi meningkatkan keterampilan berpikir kritis siswa karena siswa berlatih melakukan penyelidikan 
mulai dari menyusun pertanyaan, menyusun hipotesis, menghimpun data, menganalisis data sampai dengan menarik kesimpulan. Ibe (2013) menjelaskan bahwa model pembelajaran inkuiri terbimbing memfasilitasi siswa untuk mengembangkan berpikir kritis.

Keterampilan berpikir kritis yang diteliti meliputi kemampuan melakukan deduksi, melakukan induksi, memberikan argumentasi, dan melakukan evaluasi. Siswa berlatih melakukan deduksi ketika melakukan penyelidikan dalam proses pembelajaran. Kegiatan penyelidikan dimulai dari menyusun pertanyaan, kemudian siswa mengumpulkan data yang bersifat umum, dilanjutkan dengan diskusi kelompok untuk menganalisis data dan menyimpulkan sesuai dengan pertanyaan yang telah disusun. Siswa berlatih melakukan induksi dari kegiatan menyusun pertanyaan, kemudian siswa mengumpulkan data yang bersifat khusus, dilanjutkan dengan diskusi kelompok untuk menganalisis data dan menarik kesimpulan yang bersifat umum. Kemampuan memberikan argumentasi dilatih ketika siswa melakukan diskusi dalam kelompok dan diskusi kelas. Kegiatan diskusi memfasilitasi siswa untuk saling mengemukakan pendapat. Gokhale (2004) menyatakan bahwa siswa yang menggunakan diskusi dalam pembelajaran memiliki tingkat berpikir kritis lebih baik dibandingkan siswa yang belajar secara individual. Kemampuan melakukan evaluasi dilatih ketika siswa menyaring informasi berupa fakta dan konsep yang didapatkan saat melakukan penyelidikan agar dapat menarik kesimpulan yang tepat. Zaini (2018) melaporkan bahwa model pembelajaran inkuiri berpengaruh terhadap pengembangan kemampuan menganalisis dan mengevaluasi.

Model pembelajaran inkuiri terbimbing didasari oleh filosofi konstruktivisme yang menempatkan siswa sebagai subjek pembelajaran. Model pembelajaran inkuiri terbimbing memfasilitasi siswa untuk aktif dalam proses pembelajaran, sedangkan siswa yang mengikuti pembelajaran konvensional cenderung pasif. Sanjaya (2013) menjelaskan bahwa pembelajaran konvensional bersifat terpusat pada guru sehingga kurang efektif untuk melatih keterampilan berpikir kritis. Pembelajaran dengan model inkuiri terbimbing melatih siswa untuk membangun pengetahuannya melalui langkah-langkah pembelajaran. Penelitian ini memperlihatkan bahwa model pembelajaran inkuiri terbimbing dengan langkah-langkah pembelajarannya mampu meningkatkan keterampilan berpikir kritis siswa yang meliputi kemampuan deduksi, induksi, argumentasi, dan evaluasi. Hal ini sejalan dengan laporan Ningsyih (2016) bahwa pembelajaran inkuiri terbimbing berpengaruh positif terhadap keterampilan berpikir kritis dan hasil belajar. Kristanto (2017) melaporkan hal senada, bahwa penerapan model pembelajaran inkuiri terbimbing meningkatkan keterampilan berpikir kritis.

\section{Pengaruh Kemampuan Akademik terhadap Keterampilan Berpikir Kritis}

Uji anakova ganda memperlihatkan terdapat pengaruh signifikan kemampuan akademik terhadap keterampilan berpikir kritis dengan nilai Sig. sebesar 0,003 $(<0,05)$. Kelompok kemampuan akademik tinggi dan kelompok kemampuan akademik rendah menunjukkan peningkatan keterampilan berpikir kritis. Namun capaian peningkatan keterampilan berpikir kritis pada kedua kelompok berbeda. Peningkatan keterampilan berpikir kritis lebih tinggi pada kelompok kemampuan akademik tinggi. Sedangkan kelompok kemampuan akademik rendah menunjukkan peningkatan yang cukup. Peningkatan pada kedua kelompok tersebut memiliki perbedaan yang signifikan. Redd, dkk (2001) menjelaskan bahwa tingkat kemampuan akademik siswa dapat memengaruhi capaian akademik. Warouw (2008) melaporkan bahwa kemampuan akademik berpengaruh secara signifikan terhadap hasil belajar. Edwards dan Bries (2000) mengungkapkan bahwa pencapaian berpikir tinggi pada kemampuan akademik tinggi lebih baik dibandingkan pada kemampuan akademik rendah. Newman-Ford, dkk (2009) melaporkan bahwa siswa yang memiliki kualifikasi tinggi secara konsisten akan memperoleh hasil yang lebih tinggi dibandingkan siswa yang memiliki kualifikasi rendah.

Capaian akademik selain dipengaruhi oleh kemampuan akademik juga dipengaruhi oleh motivasi. Suryabrata (2006) menjelaskan bahwa motivasi adalah keadaan yang mendorong seseorang untuk bertindak dalam rangka mencapai tujuan. Saleh (2014) melaporkan bahwa terdapat pengaruh signifikan antara motivasi terhadap prestasi akademik. Purwanto (2014) memaparkan bahwa siswa akan memiliki motivasi berprestasi tinggi jika memiliki nilai tugas tinggi, efikasi tinggi, serta dengan orientasi tujuan tinggi. Siswa dengan nilai tugas tinggi memiliki keyakinan bahwa pelajaran dan aktivitas belajar yang dilakukan adalah hal yang berharga dan penting. Siswa dengan efikasi diri tinggi memiliki keyakinan bahwa dirinya memiliki kemampuan akademik dan mampu mengatur perilakunya supaya mencapai keberhasilan dalam belajar. Siswa dengan orientasi tujuan tinggi memiliki sasaran capaian pembelajaran yang jelas. Dengan demikian, dapat ditegaskan bahwa motivasi berprestasi pada kelompok akademik tinggi lebih tinggi dibanding pada kelompok akademik rendah.

\section{Pengaruh Interaksi Antara Inkuiri Terbimbing dan Kemampuan Akademik Terhadap Keterampilan Berpikir Kritis}

Hasil uji anakova ganda memperlihatkan tidak ada pengaruh interaksi inkuiri terbimbing dan kemampuan akademik. Perolehan F hitung untuk interaksi antara inkuiri terbimbing dan kemampuan akademik sebesar 3,459 dan sig 0,070 (>0,05). Tidak adanya interaksi antara inkuiri terbimbing dan kemampuan akademik terhadap keterampilan berpikir kritis bermakna bahwa inkuiri terbimbing dapat diterapkan pada semua tingkatan kemampuan akademik, baik tinggi maupun rendah. Keterampilan berpikir kritis pada kelas yang diterapkan inkuiri terbimbing lebih tinggi dibanding pada kelas yang diterapkan pembelajaran konvensional, baik pada kemampuan akademik tinggi maupun kemampuan akademik rendah. 
Pembelajaran inkuiri terbimbing dilaksanakan sesuai dengan sintaks inkuiri terbimbing. Sintaks yang diimplementasikan secara berurutan mulai dari menyusun pertanyaan, menyusun hipotesis, menghimpun data, menganalisis data, sampai dengan menarik kesimpulan. Pelaksanaan langkah-langkah pembelajaran ini dilakukan dalam waktu yang terbatas. Kelompok kemampuan akademik rendah memerlukan waktu yang lebih lama untuk menguasai konsep dibandingkan dengan kelompok akademik tinggi. Prayitno (2010) menjelaskan bahwa capaian penguasaan konsep pada kelompok kemampuan akademik rendah dapat menjadi sama dengan kelompok kemampuan akademik tinggi jika diberikan waktu belajar yang cukup.

\section{SIMPULAN}

Berdasarkan pemaparan data dan pembahasan dapat disimpulkan bahwa (1) penerapan inkuiri terbimbing berpengaruh signifikan terhadap keterampilan berpikir kritis siswa kelas XI SMAN 7 Malang, (2) kemampuan akademik (tinggi dan rendah) berpengaruh signifikan terhadap keterampilan berpikir kritis siswa kelas XI SMAN 7 Malang, dan (3) tidak ada pengaruh interaksi antara inkuiri terbimbing dan kemampuan akademik terhadap keterampilan berpikir kritis siswa kelas XI SMAN 7 Malang.

Hasil penelitian ini memperlihatkan pengaruh positif penerapan inkuiri terbimbing terhadap pengembangan keterampilan berpikir kritis pada siswa kelas XI SMAN 7 Malang. Oleh karena itu, guru Biologi kelas XI dapat menerapkan inkuiri terbimbing untuk melatih pengembangan keterampilan berpikir kritis.

\section{DAFTAR RUJUKAN}

Arikunto, S. (2012). Dasar-Dasar Evaluasi Pendidikan Edisi 2. Jakarta: Bumi Aksara.

Bransford, J. D., Brown, A. L., \& Cocking, R. R. (2002). How People Learn: Brain, Mind, Experience, and School. Washington DC: National Academy Press.

Corebima, A. D., \& Agil, A. (2006). Pengaruh Pembelajaran berpola PBMP (TEQ) terhadap Kemampuan Berpikir dan Pemahaman Konsep pada Pembelajaran IPA Biologi di Beberapa SMPN Kota dan Kabupaten Malang Indonesia. Makalah pada Seminar Biologi Kebangsaan di UPSI Kuala Lumpur. Malaysia, 26-28 Juni 2006.

Edwards, M. C., \& Bries, G. E. (2000). Higher Order and Lower Order Thinking Skill Achievement in SecondaryLevel Animal Science. Does Block Shceduling Pattern Influence End-of Course Learner Performance. Journal of Agricultural Education, 41(4), 2-14.

Gokhale, A. A. (2004). Collaborative Learning Enhances Critical Thinking. Journal of Technology Education, 7(1), 1-74. Hamalik, O. (2007). Dasar-Dasar Pengembangan Kurikulum. Bandung: Remaja Rosdakarya.

Hapsari, D., Sudarisman, S., \& Marjono. (2012). Pengaruh Model Inkuiri Terbimbing dengan Diagram V dalam Pembelajaran Biologi terhadap Kemampuan Berpikir Kritis dan Hasil Belajar Siswa. Jurnal Pendidikan Biologi, 4(3), 16-28.

Hassoubah, Z. I. (2004). Developing Creative and Critical Thinking Skills (Cara Berpikir Kreatif dan Kritis). Bandung: Nuansa.

Hendi, R. P. (2010). Pembelajaran Berbasis Inkuiri Terbimbing dengan Multimedia dan Lingkungan Riil Ditinjau dari Motivasi dan Kemampuan Awal Siswa. Tesis tidak diterbitkan. Universitas Sebelas Maret, Surakarta.

Ibe, Helen, N. N. (2013). Effects of Guided-Inquiry and Expository Teaching Methods on Senior Secondary School Students' Performances in Biology in Imo State. Journal of Education Research and Behavioral Sciences, 2(4), $51-57$.

Kristanto, Y E., Susilo, H., (2015). Pengaruh Model Pembelajaran Inkuiri Terbimbing terhadap Kemampuan Berpikir Kritis dan Hasil Belajar IPA Siswa Kelas VII SMP. Jurnal Pendidikan dan Pembelajaran, 22(2), 197-208.

Mamu, H. D. (2014). Pengaruh Strategi Pembelajaran, Kemampuan Akademik dan Interaksinya terhadap Keterampilan Berpikir Kritis dan Hasil Belajar Kognitif IPA Biologi. Jurnal Pendidikan Sains, 2(1), 1-11.

Minner, DD, Levy, AJ. \& Century, J. (2010). Inquiry based science instruction -what is it and does it matter? Results from a research synthesis years 1984 to 2002. Journal of Research in Science Teaching, 47, 474-496.

Nasution, S. (2008). Berbagai Pendekatan dalam Proses Belajar Mengajar. Jakarta: Bumi Aksara.

Newman-Ford, L., Lloyd S., \& Thomas, S. An Investigation into the Effects of Gender, Prior Academic Achievement, Place of Residence, Age, and Attedance on Firs-Year Undergraduate Attainment. 2009. Journal of Applied Research in Higher Education, 1(1), 13-28.

Ningsyih, S., Junaidi, E., \& Idrus, S. (2016). Pengaruh Pembelajaran Praktikum Berbasis Inkuiri Terbimbing terhadap Kemampuan Berpikir Kritis dan Hasil Belajar Kimia Siswa. Jurnal Pijar MIPA, XI(1), 55—59.

Prayitno, B. A. (2011). Pengembangan Perangkat Pembelajaran IPA Biologi SMP Berbasis Inkuiri Terbimbing Dipadu Kooperatif STAD serta Pengaruhnya terhadap Kemampuan Berpikir Tingkat Tinggi, Metakognisi, dan Keterampilan Proses Sains pada Siswa Berkemampuan Akademik Atas dan Bawah. Disertasi tidak diterbitkan. Universitas Negeri Malang, Malang.

Purwanto, E. (2014). Model Motivasi Trisula: Sintesis Bari Teori Motivasi Berprestasi. Jurnal Psikologi, 41(20), 218 -228.

Ramdani, A. (2012). Pengembangan Perangkat pembelajaran Inkuiri Melalui Kegiatan Lesson Study Serta Pengaruhnya terhadap Hasil Belajar IPA Biologi dan Keterampilan Berpikir Kritis Siswa Berkemampuan Akakdemik Berbeda di SMP Negeri Kota Mataram. Disertasi tidak diterbitkan. Universitas Negeri Malang, Malang. 
Redd, Z. Brooks, J., \& McGarvey, A. M. (2011). Background for Community Level Work on Educaional Adjustment in Adolescence: Reviewing the Literature on Contributing Factors. Child Trends. Prepared for the John S. and Jomes L. Knight Foundation

Saleh, M. (2014). Pengaruh Motivasi, Faktor Keluarga, Lingkungan Kampus, dan Aktif Berorganisasi terhadap Prestasi Akademik. Jurnal Phenomenon, 4(2), 109-141.

Sanjaya. (2013). Strategi Pembelajaran Berorientasi Standar Proses Pendidikan. Jakarta: Kencana Prenada Media Group.

Sugiyono. (2015). Metode Penelitian Pendidikan. Bandung: Alfabeta.

Suryabrata, S. (2006). Psikologi Pendidikan. Jakarta: PT Raja Grafindo Persada.

Warouw, Zusje W. M. (2009). Pengaruh Pembelajaran Metakognitif dalam Strategi Cooperative Script dan Reciprocal Teaching pada Kemampuan Akademik Berbeda terhadap Kemampuan dan Keterampilan Metakognitif, Berpikir Kritis, Hasil Belajar Biologi Siswa, serta Retensinya di SMP Negeri Manado. Disertasi tidak diterbitkan. Universitas Negeri Malang, Malang.

Woolfolk, A. (2010). Educational Psychology. United States of America: Pearson Education International.

Zaini, M., Kapsul., \& Rezeki, A. (2018). Hasil Belajar dan Keterampilan Berpikir Kritis Siswa SMA pada Pembelajaran Biologi menggunakan Model Inkuiri. BIOEDUKASI: Jurnal Pendidikan Biologi, 11(1), 17-22.

Zubaidah, S. (2002). Beberapa Alternatif Pembelajaran untuk Meningkatkan Pemahaman terhadap Istilah atau Konsep Biologi. Jurnal Pendidikan dan Pembelajaran, 9(1). 